\title{
Indonesia's Export-Import Analisys: Granger Causality Approach
}

\author{
Syaparuddin ${ }^{1 *}$ \\ ${ }^{1}$ University of Jambi, Jambi, Indonesia
}

\begin{abstract}
In a global economy context, the role of export-import becomes really important in supporting economic growth. An interesting phenomenon is that, most of Indonesian export are import-content and capital goods.

This study is aimed at (1) analyzing Indonesia's export-import patterns, (2) analyzing causality relationship between export and import in Indonesia. Analysis method used in this research is Granger Causality model. The result of study shows that the patters of the progress and the changes of Indonesia's export and import have similar patters since 1980-2015. Those have causality relationship which indicate that export and import are mutual dependence.

The conclusion of the research is that when Indonesia's export would be increased so import should also be increased. On the other hand, the increasing of import must also be preceded by the increasing in export.
\end{abstract}

JEL Classification: F13, F17, F18

Keywords: Export, Important and Causality Granger

\section{INTRODUCTION}

In the context of national economy, the role of export and import is really important beside society's consumption expenditure, private investment and government expenditure. The number of export and import in a country's economy also describes the economy openness of such state. Theoretically the bigger the difference between export and import, so the smaller the difference between export to import value or deficit happened to such trade balance (export net negative), so the smaller the ability of such state to drive its economic growth.

Phisically, export means as the sending or the selling of domestically - produced goods to foreign countries. The sending would create income to private sectors. By such condition, aggregate demand would increase and eventually it would increase national income as well. On the other hand, import is an activity of buying foreignproduced goods and it would, of course, decrease national income. This shows that the effect of export and import towards national income balance greatly depends on the number of exports minus import.

Export and Import is really important in forming and controlling trade balance in a country. Import must be funded with the same value from export to maintain trade balance in order to be equilibrium. Therefore a country should do the export activity to finance import which is paid with foreign currency.

As a country with open economy, the domination of society's consumption expenditure toward indonesian's economy is so big. Until 2014, the role of society's

* Corresponding author. Email address: syapruddinjambione@gmail.com,

katamso.sa@gmail.com 
consumption expenditure toward indonesian's economy was $55.05 \%$, government expenditure was $7,56 \%$, constant capital forming as the reflection of private investment expenditure was $24,72 \%$, while the role of export-import was ( $44 \%$ $33,92 \%$ ) or the role of export netto was $10,61 \%$ (BPS,2015) .

Although the role of export-import toward s Indonesian economy is not so as big as the society's consumption expenditure but partly the role of export is so huge. If the value of import could be more reduced into the most important part in forming Indonesian economy. By looking at Indonesia export commodities, beside textile, dominantly Indonesian export come from other primary commodities such as agriculture (plantation and fishery) and mining commodity such as oil and gas, coal in which their raw material come from domestic.

In other side, when being seen from Indonesian import, Non oil and gas import dominated Indonesian import since 1990-2014 with each avegare composition during such period was $79 \%$ (non oil and gas) and $21 \%$ (oil and gas). In the same period, Indonesian import in term of raw material and assisting goods had dominated with each composition $75 \%$, then capital goods $18 \%$ and consumption goods $7 \%$.

The experience shows that when economic crisis hit Indonesia in 1997-1998, term of trade of Rupiah towards foreign currency depreciated sharply and it had bad impact toward the value of indonesian import which went down sharply from US\$.42.928.5 billion in 1996 became US\$.27.336.9 billion in 1998. The declining import ability in Indonesia had also affected Indonesia's ability to drive exports particularly imported-raw material goods and capital goods. Those two kinds of goods had direct relation to production process. Negative growth of raw material and capital goods imports had implication to production process.

For the developing countries including Indonesia, import is intended to support industrialization process. Therefore the bigger number of import in term of raw materials for industry, machines or other capital goods, is aimed at producing certain goods for domestic needs or for export needs.

\section{RESEARCH METHOD}

\subsection{Kind and Data source}

Data used in this research are secondary, consisting data of export, impor and Indonesian PDB 2000-2014 which come from Indonesian Statistic Bureau, ADB Key Indicators and Ministry of Trade Republic of Indonesia. 


\subsection{Analysis Method}

To Analyze the pattern of Indonesian export and import, Descriptive analysis by using table and graph was used. In order to analyze the causality relationship between Indonesian export and import, Causality Granger was then used. This Causality was firstly introduced by Engel and Granger. In this research context, the purpose of Granger causality is whether export preceded import or import preceded export or causality relationship between export and import. Causality relationship could take place between two variables. Causality test could also look at the past impact towards present condition or in the contrary. By another word, Granger causality test could also be used to have a look at Prediction $\mathrm{Y}$ in more accurate by inserting lag variable X. the model is : (Juanda dan Junaidi, 2012)

$$
\begin{aligned}
& E X P t=\sum_{t=1}^{m} \alpha \mathrm{EXPt}-1+\sum_{j=1}^{m} \beta \mathrm{j} \mathrm{IMPt}-\mathrm{j}+\mathrm{U} 1 \mathrm{t} \\
& I M P t=\sum_{t=1}^{m} \lambda_{\mathrm{i} I M P t}-1+\sum_{j=1}^{m} \delta_{\mathrm{j}} \operatorname{EXPt}-\mathrm{j}+\mathrm{UZ2t}
\end{aligned}
$$

$$
\begin{aligned}
& \text { Where : } \\
& \text { EXP = export } \\
& \text { IMP = Import } \\
& \mathrm{m} \quad=\text { number of lag } \\
& \mathrm{u} \quad=\text { error term }
\end{aligned}
$$

there are four result possibilities obtained, namely :

1. If $\Sigma a j \neq 0$ and $\Sigma b j=0$, sothere is one way causality from $\mathrm{x}$ to $\mathrm{y}$.

2. If $\Sigma a j=0$ and $\Sigma b j \neq 0$, sothere is one way causality from yto $\mathrm{x}$.

3. If $\Sigma a j=0$ and $\Sigma b j=0$, so there is no causality between $\mathrm{x}$ and $\mathrm{y}$.

4. If $\Sigma a j \neq 0$ dan $\Sigma b j \neq 0$, sothere is two-way causalitybetween $\mathrm{x}$ and y.

\section{RESULT AND DISCUSSION}

\subsection{The pattern of Indonesian's Export and Import.}

The role of export and import in driving economic growth or domestic product in a country is greatly important. In some countries their roles are more than the role of investment and government expenditure. When net export (surplus) so it would drive the increasing of PDB. Export and import are one of the keys to a country's economic growth, beside consumption, investment and government expenditure. Historically, the economic growth of developed countries were supported by their export growth until such countries dominated world's export. In 2006, West Europe, USA and Japan as developed countries owned export market, each of them were $16.40 \% ; 8,02 \%$ and $5,38 \%$. Other countries such as China with its export share $8.59 \%$ (WTO,2008 in Adrian D Lubis). 
In macro economy, the role of export and import in a country's economy can be seen in the following formula : (Branson, 1989)

$$
\mathrm{GNP}=\mathrm{C}+\mathrm{I}+\mathrm{G}+(\mathrm{X}-\mathrm{M})
$$

In which :

$\begin{array}{ll}\text { GNP } & =\text { Gross National Product } \\ \text { C } & =\text { Society's consumption } \\ \text { I } & =\text { Private Investment } \\ \text { G } & =\text { Government Expenditure } \\ \text { X } & =\text { Export } \\ \text { M } & =\text { Import }\end{array}$

Based on the above formula, it could be explained that export and import in economy should be integrated. It means that they could not be parted away one by one. This is caused by when (X-M) negative, so the role of export is meaningles. Export would play important role in economy when $(\mathrm{X}-\mathrm{M})$ is positive. It means that there is a surplus in trade balance, so it would drive economy. This argument was supported by Tan (2004) which stated that the role of export and import towards GDP could be seen from foreign currency receipts and then it drives import, in turn, it would drive invenstment and finally it would drive the increasing of GDP.

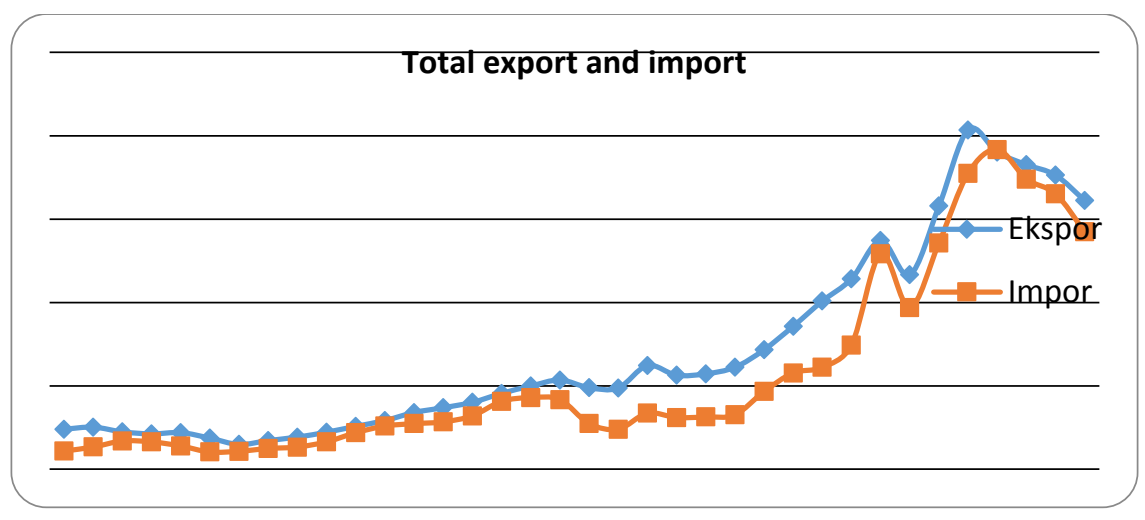

Figure 1 the Pattern of Indonesian Export and Import 1980-2015

World trade liberalization causes the openness in Indonesian economy, it means that the export opportunity is greatly important (Tulus TH Tambunan, 2012). So the role of export in economy is getting bigger. The interesting phenomena in Indonesian economy is that ; based on the data that the raw material must be imported. When economic crisis happened, the ability of buying imported goods would also decline, as the impact, the number of export with imported row materials would eventually decline sharply.

There is an interesting phenomena in the relationship between Indonesian export and import during 1980-2015 as shown in figure 1 is that Indonesian export and import had the same pattern in where the increasing in export was always followed by the decreasing in import. In other side, the decreasing in import was followed by the increasing of export, on the contrary, the increasing in import was frequently followed by the decreasing of export. 


\subsection{Causality Analysis of Indonesian's export and Import.}

In this part, Granger causality was analyzed to prove the hypothesis on relationship between export and import in Indonesia during 1980-2015. In order to know such relationship, Granger causality test was conducted. This test is a test to have a look at relationship or way of causality between variables. So the partial test for each variable was conducted.

Before doing Granger causality test by using times series data, Stationerity test was done in order to know whether the data had roots unit or not. If such variables had roots unit,so the data were not stationery.

By using root unit test at level and first difference, so it could be concluded that the level of export data had roots unit or the data were not stationery, while the first difference, export data did not have roots unit or the data were stationery. Hypothesis null at ADF test stationery data with $\alpha=0,05, \mid \mathrm{ADF}$ statistic test $|>|$ critical point at significant level 5\%| namely $|-7.199256|>|-3.595026|$, this also occurred at $\alpha=1 \%$ and $\alpha=10 \%$ ( $\mid \mathrm{ADF}$ statistic test $|>|$ critical point $\mid)$ or ADF statisticat the rejected area $\mathrm{H}_{0}$.It could be concluded that the data of Import were stationery at the first difference. It mean that the dataused in this research did not have roots unit at the first difference level, so the data of Export could be used for Granger causality test.

After the test was done for roots unit at level and the first difference, so it could be concluded that the level of import data had roots unit or the data were not stationery at $\alpha=0.05$, while at $\alpha=0.05$, data of import did not have roots unit or the data were stationery. As $\mid \mathrm{ADF}$ statistic test $|>|$ critical pointat level of significance $5 \%$ namely $|-3.863524|>|-3.595026|$, This also happened at $\alpha 10 \%$ (|ADF statistic test $\mid$ $>$ |critical point |) or ADF statistic was at rejected area $\mathrm{H}_{0}$. So, it could be concluded that the data of Impor were stationery. By looking at the result of the data stationery test, in fact, both data used in this research could be regarded as stationery data as they did not have roots unit, so it was reasonable for Granger causality test.

Based on the result of the research by using lag 1 at $\alpha=0.05 \%$, it was obtained that probability was 0.0061 smaller than 0.05 and at the level of failure $5 \%$, it was also obtained probability 0.0004 smaller than 0.05 . bt using $F$ test, where $\mathrm{F}_{\text {statistic }}=$ 8.63170 and 15.3756, it was concluded that Export and import in Indonesia has causality, it means that export affects import and on the other hand import affects export. By lag 1 export would affect import and vise versa.

Pairwise Granger Causality Tests

Date: 08/29/16 Time: 16:26

Sample: 19802015

Lags: 1

\begin{tabular}{|c|c|c|c|c|}
\hline & & $\mathrm{O}$ & F- & $\operatorname{Pr}$ \\
\hline Null Hypothesis: & bs & & Statistic & ob. \\
\hline IMPOR does not Granger Cause & & 3 & 8.6 & 0.0 \\
\hline EKSPOR & 5 & & 3170 & 061 \\
\hline EKSPOR does not Granger Cause IMPOR & & & $3756^{15 .}$ & $\begin{array}{r}0.0 \\
004\end{array}$ \\
\hline
\end{tabular}


By using lag 2 at level of confidence $95 \%$ or $\alpha=5 \%$, it was obtained that probability was 0.0083 smaller than 0.05 and at the level of failure $5 \%$,it was also obtained probability 0.0017 smaller than 0.05 . by using $F$ test, df $1 ; 32$, so $F_{\text {statistic }}>$ $\mathrm{F}_{\text {table }}(5.67934>3.15)$ dan $(8.04274>3.15)$ means that $\mathrm{H}_{0}$ rejected. It means that export had two-ways relationship or export affects import and vise versa during 2 years. While import also had two-ways relationship with export.

Pairwise Granger Causality Tests

Date: 08/29/16 Time: 16:36

Sample: 19802015

Lags: 2

\begin{tabular}{|c|c|c|c|c|}
\hline & & $\mathrm{O}$ & F- & $\operatorname{Pr}$ \\
\hline Null Hypothesis: & bs & & Statistic & ob. \\
\hline IMPOR does not Granger Cause & & 3 & 5.6 & 0.0 \\
\hline EKSPOR & 4 & & $\begin{array}{r}7934 \\
8.0\end{array}$ & $\begin{array}{r}083 \\
0.0\end{array}$ \\
\hline EKSPOR does not Granger Cause IMPOR & & & 4274 & 017 \\
\hline
\end{tabular}

Based on the result of this research, in Indonesia, there was causality relationship between export and import or there was causality relationship between export and import. This indicated that the increasing of export would have an impact towards the increasing of import and vise versa, the decreasing of export would decrease import. The decreasing of Import would have an impact toward the decreasing of export in Indonesia. This condition would be really possible to happen by watching the pattern of export and import in Indonesia during 1980-2015. 
Table 1 Export and Import in Indonesia 1980-2015

\begin{tabular}{rrrrrrr}
\hline \multirow{2}{*}{ Year } & \multicolumn{2}{c}{ Non Oil and gas } & \multicolumn{2}{c}{ Oil and Gas } & \multicolumn{2}{c}{ Total } \\
\cline { 2 - 7 } & \multicolumn{1}{c}{ Export } & \multicolumn{1}{c}{ Import } & \multicolumn{1}{c}{ Export } & \multicolumn{1}{c}{ Import } & \multicolumn{1}{c}{ Export } & \multicolumn{1}{c}{ Import } \\
\hline 1980 & 6168.8 & 9090.4 & 17781.6 & 1744 & 23950.4 & 10834.4 \\
1985 & 5868.9 & 8983.5 & 12717.8 & 1275.6 & 18586.7 & 10259.1 \\
1990 & 14604.2 & 19916.6 & 11071.1 & 1920.4 & 25675.3 & 21837 \\
1995 & 34953.6 & 37717.9 & 10464.4 & 2910.8 & 45418 & 40628.7 \\
1996 & 38093 & 39333 & 11721.8 & 3595.5 & 49814.8 & 42928.5 \\
1997 & 41821.1 & 37755.7 & 11622.5 & 3924.1 & 53443.6 & 41679.8 \\
1998 & 40975.5 & 24683.2 & 7872.1 & 2653.7 & 48847.6 & 27336.9 \\
1999 & 38873.2 & 20322.2 & 9792.2 & 3681.1 & 48665.4 & 24003.3 \\
2000 & 47757.4 & 27495.3 & 14366.6 & 6019.5 & 62124 & 33514.8 \\
2005 & 66428.4 & 40243.2 & 19231.6 & 17457.7 & 85660 & 57700.9 \\
2010 & 129739.5 & 108250.6 & 28039.6 & 27412.7 & 157779.1 & 135663.3 \\
2013 & 149918.8 & 141363.3 & 32633.03 & 45459.9 & 182551.8 & 186823.2 \\
2014 & 145960.8 & 134718.9 & 30331.9 & 43459.9 & 176292.7 & 178178.8 \\
2015 & 136822.7 & 118126.4 & 24253.2 & 24613.2 & 161075.9 & 142739.6 \\
\hline
\end{tabular}

Source: BPS Indonesia

There was causality relationship between export and import in Indonesia during 1980-2015. It would possibly happen as the import content mainly raw materials for exported-goods and capital goods such as assisting row materials and capital goods at which they contributed $60-70 \%$ of Indonesian import totally. It means that Indonesia is Textile-exporting country in the world but the raw material is imported ones.

The real condition about the relationship between export and import could be proven in the economic crisis in 1997 - 1999. During such period Indonesian export underwent a very sharp decline in one side and in other side, import value declined sharply as well. Economic crisis with the impact of depreciated Rupiah currency had caused the price of imported-goods more expensive, so the ability to buy imported-goods became lessened. As the effect, the ability to drive the increasing of import got lessened as well. This could clearly seen mainly at non-oil and gas export, in where the decreasing in import mainly at lag 1 had caused the decreasing in export.

\section{SUMMARY AND SUGGESTIONS}

Based on the result of the research, it is concluded that the pattern of Indonesian export and import during 1980-2015 are relatively similar. There is causality relationship between export and import both at lag 1 and lag 2 . Therefore the increasing of export in Indonesia should be conducted with the same way to increase import and the increasing of import could be reached if the export value would increase. 


\section{References}

Branson, W. H.. (1989). Macroeconomic Theory and Policy, Third Edition. New York: Harper and Row.

Ilham, M., \& Suparyati, A. (2014). Causality Analisys of Export and Import,and economic growth ind Indonesia and Thailand by VAR Approach 1980-2013. Economic development Journal. E-Journal. Trisakti. February 2014.

Juanda, B., \& Junaidi. (2012). Times series econometrics and Aplication.IPB. PT IPB Press.

Lubis, A. D. The Analisys of factors affecting indonesia's export performances. Resercher at The Foreign trade research and development Centre. Ministry of Trade.

Salvatore, D. (1997). International economics, The 5th edition Translation. Jakarta:Erlangga.

Statistic Central Agency. (2015). Indonesia's export-import statictic. Jakarta: Statistic Central Agency.

Tan, S. (2004). International economics. Economic Faculty, Jambi University. Jambi

Tambunan, T. T. H. (2012). Indonesia's Economy : Theoritical observation and empirical analisys. Jakarta: Ghalia Indonesia.

Wiryono, W. W. (2015). Econometrics and Statistics analisys by Eviews, the Fourth Edition. UPP STIM YKPN. Yogyakarta. 